Arch. Tierz., Dummerstorf 50 (2007) 1, 59-70

Research Institute for the Biology of Farm Animals Dummerstorf, Germany

RALF PFUHL, OLAF BELLMANN, CHRISTA KÜHN, FRIEDRICH TEUSCHER, KLAUS

ENDER and JOCHEN WEGNER

\title{
Beef versus dairy cattle: a comparison of feed conversion, carcass composition, and meat quality
}

\begin{abstract}
The objective of this study was to investigate the phenotypical differences in feed conversion, carcass composition, and meat quality of two cattle breeds representing either the accretion type (Charolais) or the secretion type (Holstein). Eighteen Charolais bulls and 18 German Holstein bulls were raised and fattened under identical conditions on a high energy level with concentrates and hay. The animals were slaughtered at the age of 18 months. Charolais bulls had a body weight (BW) of $750.6 \mathrm{~kg}$ and an average daily gain (ADG) of $1377 \mathrm{~g}$. German Holstein bulls were $84.7 \mathrm{~kg}$ lighter with an ADG of $1197 \mathrm{~g}$. The energy expense per kg BW gain was 14\% lower in the Charolais bulls compared with German Holstein. Charolais bulls gained more energy in protein than the Holstein bulls and needed less energy per kg protein gain in the hot carcass weight (HCW). The Charolais bulls showed a greater carcass weight and a higher yield grade as well as a greater cross sectional area of the $M$. longissimus dorsi (LD). Holstein bulls showed a greater marbling score, darker color, and more water binding capacity of the LD. The Holstein bulls gained more subcutaneous, intramuscular, and visceral fat during growth, which reflects the ability of the Holstein as a dairy breed to deposit fat as an energy source for milk production and points out the capability of Charolais for extended protein accretion. The genetic background of the recorded different nutrient utilization and turnover will be investigated in further experiments.
\end{abstract}

Key Words: beef cattle, dairy cattle, carcass composition, meat quality, Charolais, German Holstein

\section{Zusammenfassung}

Titel der Arbeit: Fleisch- versus Milchrind: Ein Vergleich der Futterverwertung, Schlachtkörperzusammensetzung und Fleischqualität

Das Ziel dieser Arbeit war die Untersuchung phänotypischer Unterschiede in Futterverwertung, Schlachtkörperzusammensetzung und Fleischqualität bei Bullen unterschiedlicher Stoffwechseltypen. Achtzehn Charolaisbullen für den Ansatztyp und 18 Holsteinbullen für den Umsatztyp wurden unter gleichen Bedingungen aufgezogen und auf einem hohen Energieniveau mit Heu und Kraftfutter gemästet. Die Tiere wurden im Alter von 18 Monaten geschlachtet. Die Charolaisbullen hatten ein Mastendgewicht von $750.6 \mathrm{~kg}$ und eine durchschnittliche tägliche Zunahme von 1377 g. Die Holsteinbullen waren bei gleichem Alter 81.7 kg leichter mit einer durchschnittlichen täglichen Zunahme von 1197 g. Der Energieaufwand pro kg Körpergewichtszunahme war bei den Charolaisbullen 14\% geringer als bei den Holsteinbullen. Die Charolaisbullen setzten mehr Energie in Protein um und benötigten dabei weniger Energie pro kg Proteinzuwachs als die Holsteinbullen. Die Charolaisbullen zeigten eine höhere Mastendmasse, einen höheren Schlachtertrag und eine größere Kotelettfläche, wogegen die Holsteinbullen eine stärkere Marmorierung, ein höheres Wasserbindungsvermögen und dunklere Farbe des $M$. longissimus dorsi (LD) zeigten. Die Holsteinbullen setzten mehr subkutanes, intramuskuläres und Organfett als Charolaisbullen an. Dies spiegelt die Fähigkeit der Holsteinrasse wider, Fett als Energiedepot für den gesteigerten Energiebedarf der Milchproduktion anzulegen und zeigt im Gegensatz die Fähigkeit der Charolaisbullen für einen extremen Proteinansatz. Die zugrunde liegenden Mechanismen der beobachteten, unterschiedlichen Futterverwertung und des unterschiedlichen Nährstoffsumsatzes sind Gegenstand weiterer Untersuchungen.

Schlüsselwörter: Fleischrind, Milchrind, Schlachtkörperzusammensetzung, Fleischqualität, Charolais, Deutsche Holstein

\section{Introduction}

Cattle breeding in the past century resulted in the development of specialized meat and dairy breeds. Improved breeding methods as well as the application of biotechnology 
(artificial insemination, embryo transfer) boosted the efficiency of cattle production. Major changes in carcass composition are always produced at the risk of upsetting nature's homeostasis with respect to functional requirements, which have developed in each species over its evolutionary history (BERG and WALTERS, 1983). Against the background of these developments, the ability of cattle to transform their nutrient uptake either in body tissue or in milk secretion is not completely understood.

The comparative investigation of growth, carcass traits, and meat quality is important for a comprehensive characterization of different breeds (KOCH et al., 1982). Several investigations have been made to characterize traits like carcass yield and body composition, which images the different genetic predisposition between breeds (COLEMAN et al., 1993; FERRELL and JENKINS, 1998). In most of the studies, crossbred animals were used to investigate growth and carcass traits for a prediction of breeding and fattening performance. Even the majority of experiments about feed efficiency of cattle were indeed conducted with crossbreds (FORREST, 1977; MANDELL et al., 1997). No study was conducted comparing Charolais and Holstein bulls regarding the differences of nutrient utilization between breeds and its possible physiological background. Several approaches have been made to reveal the endocrinological background of nutrient utilization in cattle (BELLMANN et al., 2004a; BELLMANN et al., 2004b). The objective of this study was to characterize the phenotypical differences in feed conversion, carcass composition, and meat quality between Charolais, as an accretion type, and Holstein, as a secretion type, on a high feeding level.

\section{Animals}

\section{Materials and Methods}

The animals used in this study were part of the segregating families herd, currently under investigation at the Research Institute for the Biology of Farm Animals in Dummerstorf. (KÜHN et al., 2002). From this herd, 18 purebred Charolais bulls, representing the accretion type of cattle and 18 purebred German Holstein bulls, representing the secretion type of cattle were used. Starting at the age of 7 days, all calves were raised on a milk replacer diet under standardized conditions until 120 days of age in the experimental unit of the Research Institute for the Biology of Farm Animals. From the 5. to the 18. month of age, the animals were tethered on individual feeding places with semi-slatted floor and automatic drinking bowls. The ration was offered ad libitum and was composed of a concentrate (44.8\% barley, 36.9\% molassechips, $13.7 \%$ soybean extraction meal, $3 \%$ molasses, and $1.6 \%$ mineral and vitamin premix) and chaffed hay in the proportion 3:1, resulting in an energy content of 11.7 MJ ME/kg dry matter (DM) of feed. Any unconsumed feed was removed, weighted and recorded daily. The feed conversion ratio (FCR) was calculated, dividing the DM intake by the average daily gain (ADG). Samples of all feed components were obtained monthly and analyzed for nitrogen content and DM. To calculate the energy and fat gain, seven bulls of each breed were killed and dissected at the age of 4 months to obtain initial data on protein and fat content of the carcass. The gain of protein and fat in the carcass was calculated as the difference between the protein and fat content at 18 months of age and the initial data. To obtain the amount of energy, which was stored in protein and fat respectively, the gain of each tissue was multiplied with the conversion factor for protein (22.6) and fat (39.0) according to BÖHME and GÄDEKEN (1980). The bulls 
were weighed monthly and at the time of slaughter. The body length was measured from withers to the tail base. The hip height was measured from ground to sacrum. Pelvic floor was measured at the level of the tail base. Head width was measured upside the ears, head length from muzzle to the horn base. All body proportions were determined quarterly. The bulls were slaughtered at 18 months of age in the research institute's experimental abattoir according to a standardized protocol. All animals were cared for and killed according to German rules and regulations for animal care. The experiment was approved by the institutional authorities and by the responsible office of the County of Mecklenburg-Vorpommern, Germany (Landesveterinär- und Lebensmitteluntersuchungsamt Mecklenburg-Vorpommern).

\section{Carcass characteristics}

After slaughter, carcass weights, the amount of blood as well as the weight of the skin and the inner organs were determined. The carcasses were graded in conformation classes according to the E-U-R-O-P beef carcass classification system of the European Union, where $\mathrm{E}$ has the largest and $\mathrm{P}$ the least grade. The letters were converted into figures for better statistical analysis, whereby 1 corresponds to $\mathrm{E}$ and 5 to $\mathrm{P}$. Furthermore, the fat class was quantified according to the guidelines of the European Union from level 1 to 5 , in which 1 is the leanest and 5 the fattest level. The empty body weight (EBW) was determined according to OWENS et al. (1995) by removing all digesta from the gastrointestinal tract after slaughtering. The remaining tissues were weighed and summarized to EBW. The hot carcass weight (HCW) was defined as the carcass weight of the slaughtered animal's body after being skinned, bled, and eviscerated, and after removal of the external genitalia, the limbs at the carpus and tarsus, the head, the tail, the kidneys and kidney fats, and the scrotum.

After a 17 -h chill at $4^{\circ} \mathrm{C}$, the carcasses were weighed again to record the cold carcass weight. The chilled carcasses were dissected in various cuts (round of beef, roast beef, filet, chuck, rib, hind leg, flank, plate, brisket, and shank). Furthermore, every cut of the carcass was dissected in meat, subcutaneous fat, bones, and tendons. Body fat weight for the determination of fat gain was defined as carcass fat (summarized from the different cuts i.e. intramuscular fat, intermuscular fat, and subcutaneous fat), fat in organs, and fat in internal depots. In this study, the different components of body fat weight were determined individually after each respective tissue was ground and a sample of the ground tissue was analyzed. The protein content of all cuts was determined with Near Infrared Spectroscopy, using an Infratec 1255 Food \& Feed Analyzer (Foss Analytical A/S, Denmark). Dressing percentage was defined as the proportion of HCW and BW.

\section{Meat quality}

For the determination of meat quality traits, standard procedures were used: Tenderness at $24 \mathrm{~h}$ and $14 \mathrm{~d}$ post mortem was estimated by measuring the shear force with the Warner-Bratzler shear force measuring equipment (Emerson Electric, St. Louis, MO). A muscle sample of approximately $250 \mathrm{~g}$ and $4 \mathrm{~cm}$ in thickness was wrapped in aluminum foil, heated in an oven at $160^{\circ} \mathrm{C}$ for $75 \mathrm{~min}$, and then cooled for $90 \mathrm{~min}$. Three cylinders of meat were cut with a sharpened metal tube $2.54 \mathrm{~cm}$ in diameter. These cylinders were cut and the average value of the maximal forces was taken as shear force value (OTTO and STANG, 1975). Brightness was measured with a Minolta CR 200 (Minolta Ltd, Ahrensburg, Germany) with triplicate measurement 
on the freshly cut surface of the LD 24 h post mortem using the parameter $\mathrm{L}^{*}(\mathrm{~L}=0$ designates black and $\mathrm{L}=100$ designates pure white) of the CIE Lab system. The $\mathrm{pH}$ value was measured with the pH-Star (Matthäus Company, Klausa, Germany). The intramuscular fat content of LD samples was obtained in triplicates via the Soxhlet extraction method using petroleum ether as solvent and determined gravimetrically after evaporating the extracting solvent (ASSOCIATION OF OFFICIAL AGRICULTURAL CHEMISTS, 2000). The water binding capacity was determined by the method of GRAU and HAMM (1957), modified by GROSSE et al. (1975). Marbling was scored with photographic standards in a six-point scale with $1=$ extremely low marbled and $6=$ extremely high marbled. Scoring was performed by only one experienced operator to eliminate subjective influences.

\section{Statistics}

The experimental units were 18 Charolais bulls and 18 Holstein bulls, slaughtered at 18 months of age. The considered traits were data of feed conversion, body proportions, carcass composition, and meat quality classified by breed. Along with the standard errors, the standard deviations of the subgroups are presented in order to show the variance heterogeneity caused by different breeds. Data were analyzed by the TTEST procedure for SAS Windows Version 9.1 (SAS INSTITUTE INC., 2003). If the F-test showed significant differences between the variances, the approximate $t$ statistic was used. Otherwise, the pooled variance t-test was used.

\section{Feed conversion}

\section{Results and Discussion}

The animals were fed and raised under identical conditions to exclude effects of feed and treatment. The different body and carcass traits should be the result of different nutrient utilization, which is presumably based on breed specific preferences of metabolic pathways (BREIER and SAUERWEIN, 1995). It is well known, that level and proportion of body mass accretion of cattle is influenced by the feeding level. To satisfy this fact, all animals used in this study were fed ad libitum to tap the genetically based potential of accretion. The Holstein bulls in this study consumed nearly the same amount of feed as the Charolais bulls (Tab. 1). Therefore, there was no difference in the daily intake of energy and nutrients. On the high feeding level within this study (11.7 MJ ME per kg DM), the energy expense per kg BW gain (Tab. 2) was $13.57 \%$ lower $(P<0.001)$ in the Charolais bulls, which was in agreement to the observations of GERHARDY et al. (1995) with purebred Holstein bulls and Charolais x Holstein crossbred bulls.

In this study, the Charolais bulls ingested 7.6\% less DM per kg BW. This resulted in a better feed conversion ratio (FCR) in the Charolais bulls $(P<0.001)$, which was also reported by MANDELL et al. (1997) in a comparison of Charolais and Limousin steers. BLOCK et al. (2001) found a FCR of 6.27 in Charolais crossbred steers. These data were collected on crossbred steers with a two step feeding and ad libitum access to a high concentrate diet only in the finishing period. The FCR recorded by BLOCK et al. (2001) is in a comparable order of magnitude as observed in the present study. CHAMBAZ et al. (2001a) recorded a poorer feed efficiency in Charolais bulls with 18 months of age compared to the present study. On the high feeding level in the present study, the Charolais bulls showed a higher growth capacity with a final BW of 750.6 
kg compared to Holstein bulls and an ADG of $1377 \mathrm{~g}$. These data were also confirmed by FRELICH et al. (1998), who investigated Charolais crossbreeds.

Table 1

Feed consumption of bulls from 5 to 18 months of age (Futteraufnahme der Bullen vom 5. bis 18. Lebensmonat)

\begin{tabular}{|c|c|c|c|c|c|}
\hline & \multicolumn{2}{|c|}{$\begin{array}{l}\text { German Holstein } \\
\qquad \mathrm{n}=18\end{array}$} & \multicolumn{2}{|c|}{$\begin{array}{c}\text { Charolais } \\
n=18\end{array}$} & \multirow[b]{2}{*}{$P$-value } \\
\hline & Mean & SD & Mean & SD & \\
\hline \multicolumn{6}{|c|}{ Feed intake from 5 to 18 months of age } \\
\hline Concentrates, kg & 2784 & 195.3 & 2778 & 144.3 & 0.923 \\
\hline Chaffed hay, kg & 946.9 & 64.58 & 936.7 & 48.83 & 0.862 \\
\hline $\mathrm{ADG}, \mathrm{g} / \mathrm{d}$ & 1196 & 104.1 & 1377 & 95.30 & $<0.001$ \\
\hline \multicolumn{6}{|l|}{ Daily energy intake } \\
\hline $\mathrm{DM}, \mathrm{g} / \mathrm{d}$ & 8064 & 535 & 8033 & 396 & 0.597 \\
\hline $\mathrm{CP}, \mathrm{g} / \mathrm{d}$ & 1277 & 84.79 & 1272 & 62.79 & 0.851 \\
\hline Energy, MJ ME/d & 94.80 & 6.30 & 94.50 & 4.70 & 0.862 \\
\hline $\mathrm{FCR}^{\mathrm{a}}$ & 6.74 & 0.45 & 5.84 & 0.33 & $<0.001$ \\
\hline
\end{tabular}

${ }^{\mathrm{a}}$ Feed conversion ratio $=\mathrm{DM}$ intake $/ \mathrm{ADG}$

The German Holstein bulls were $84.7 \mathrm{~kg}$ lighter $(P<0.001)$ with an ADG of $1196 \mathrm{~g}$. These results comply with GERHARDY et al. (1995), who found purebred Holstein bulls 9\% lighter with a lower ADG than Charolais x Holstein crossbred bulls.

Table 2

Feed efficiency and energy accretion of bulls at 18 months of age (Futterverwertung der Bullen im 18. Lebensmonat)

\begin{tabular}{|c|c|c|c|c|c|}
\hline & \multicolumn{2}{|c|}{$\begin{array}{l}\text { German Holstein } \\
\qquad \mathrm{n}=18\end{array}$} & \multicolumn{2}{|c|}{$\begin{array}{l}\text { Charolais } \\
\text { n }=18\end{array}$} & \multirow[b]{2}{*}{ P-value } \\
\hline & Mean & SD & Mean & SD & \\
\hline DM /kg BW gain, g & 6763 & 448 & 5846 & 330 & $<0.001$ \\
\hline CP/ kg BW gain, g & 1071 & 71 & 926 & 52 & $<0.001$ \\
\hline $\mathrm{ME} / \mathrm{kg}$ BW gain, MJ & 79.52 & 5.28 & 68.77 & 3.89 & $<0.001$ \\
\hline MJ/ kg protein gain ${ }^{a}$ & 82.29 & 13.15 & 65.89 & 12.81 & $<0.001$ \\
\hline Energy accretion ${ }^{\mathrm{a} b}, \mathrm{MJ}$ & 3204 & 503 & 3678 & 475 & 0.006 \\
\hline Energy in fat ${ }^{\mathrm{a}}, \mathrm{MJ}$ & 2321 & 487 & 2396 & 491 & 0.646 \\
\hline Energy in protein ${ }^{\mathrm{a}}$, MJ & 882 & 80 & 1281 & 165 & $<0.001$ \\
\hline
\end{tabular}

${ }^{\mathrm{a}}$ in HCW

${ }^{\mathrm{b}}$ Protein and fat

BROSH et al. (1995) described an almost identical ADG and DM intake in Holstein Friesian calves fed at a high energy diet compared with the Holstein bulls in the present study. The investigated breeds utilized their ingested energy in different ways (Tab. 2).

The Charolais consumed less DM $(P<0.001)$ per kg BW gain and hence less $(P<$ 0.001) CP and ME per kg BW gain (KÜHN et al., 2002). In contrast, the Charolais bulls gained more $(P<0.001)$ energy in protein than the Holstein bulls and needed less $(P<$ 0.001 ) energy per kg protein gain in the HCW. It is interesting that Charolais and 
Holstein bulls deposited nearly the same amount $(P=0.646)$ of energy in fat, but the Charolais bulls gained more energy in the HCW. These observations will be discussed later in association with the carcass traits.

\section{Body proportions}

The body proportions of the investigated bulls at 18 months of age are shown in Table 3. The Charolais bulls showed smaller $(P<0.001)$ wither height than Holstein bulls, which was also recorded by GERHARDY et al. (1995). In the present study, the Charolais bulls showed a wider chest $(P<0.001)$ and wider $(P<0.001)$ pelvic floor. BELLOWS et al. (1993) reported similar pelvic areas in Charolais and Holstein. Generally, Holstein cattle are known for wider hips (SACCO et al., 1991), which was not observed in this study. Only the body length, which was measured between the point of shoulder and the ischium in this study, was similar $(P=0.326)$ in Charolais and Holstein as described at KÜHN et al. (2002).

Table 3

Body proportions of bulls at 18 months of age (Körpermaße der Bullen im Alter von 18 Monaten)

\begin{tabular}{lccccr}
\hline & \multicolumn{2}{c}{ German Holstein } & \multicolumn{2}{c}{ Charolais } \\
& Mean & SD & Mean & SD & $P$-value \\
\hline Wither height, cm & 139.4 & 4.2 & 131.1 & 8.2 & 0.001 \\
Hip height, cm & 144.8 & 4.5 & 138.6 & 7.0 & 0.008 \\
Body length, cm & 163.8 & 4.8 & 165.8 & 6.1 & 0.330 \\
Chest width, cm & 49.3 & 4.9 & 58.1 & 3.6 & $<0.001$ \\
Pelvic floor, cm & 53.4 & 2.8 & 62.4 & 2.5 & $<0.001$ \\
Head length, cm & 53.0 & 2.4 & 49.5 & 1.6 & $<0.001$ \\
Head width, cm & 22.4 & 0.7 & 23.4 & 1.3 & 0.015 \\
Cannon bone diameter, cm & 21.5 & 0.9 & 25.2 & 1.6 & $<0.001$ \\
\hline
\end{tabular}

\section{Carcass traits}

The body size traits are partially reflected in the carcass traits. The Charolais bulls showed greater EBW, HCW, and dressing percentage $(P<0.001)$ than the Holstein bulls (Tab. 4), which was consistent with the literature (FORREST, 1977; ARTHUR et al., 1995). The Charolais bulls also showed a greater conformation $(P<0.001)$ and lower fat class $(P=0.011)$. GERHARDY et al. (1995) observed a greater ratio of lean to fat combined with large carcasses in Charolais $\mathrm{x}$ Holstein crossbred bulls compared to purebred Holstein bulls.

KÖGEL et al. (2000) found similar results in Charolais x Fleckvieh bulls. Generally, the findings support the ability of Charolais bulls for greater protein accretion and high carcass yield.

Table 4 shows the absolute and relative composition of the carcass. The carcass of the Charolais bulls gained more meat $(P<0.001)$, which confirmed the results of FORREST (1977). The bone percentage of Charolais was $2.5 \%$ lower $(P<0.001)$ due to the greater weight of meat, which confirmed the observations of FORREST (1977) and ISTASSE et al. (1990). The weight of the subcutaneous fat was not different $(P=$ 0.332 ) between the breeds. The percentage of subcutaneous fat in the carcass was $15 \%$ lower $(P=0.020)$ in Charolais than in German Holstein bulls. In contrast, great 
differences were detected in the inner fat depots between the both breeds in this study as shown in Table 5. Looking into the separate fat depots reveals that Charolais bulls showed lower values in all types of inner fat $(P<0.001)$. MARSHALL (1994) and BROSH et al. (1995) reported comparable amounts of inner fat depots in Holstein bull carcasses. In addition, MATTHES et al. (1996) reported also a tendency for a greater inner fat content in bulls of the black pied dairy cattle.

Table 4

Carcass characteristics of bulls at 18 months of age (Schlachtkörpermerkmale der Bullen im Alter von 18 Monaten)

\begin{tabular}{|c|c|c|c|c|c|}
\hline & \multicolumn{2}{|c|}{$\begin{array}{l}\text { German Holstein } \\
\qquad \mathrm{n}=18\end{array}$} & \multicolumn{2}{|c|}{$\begin{array}{c}\text { Charolais } \\
\mathrm{n}=18\end{array}$} & \multirow[b]{2}{*}{$P$-value } \\
\hline & Mean & SD & Mean & SD & \\
\hline EBW, kg & 588.2 & 39.4 & 675.4 & 39.6 & $<0.001$ \\
\hline HCW, kg & 356.7 & 23.5 & 450.3 & 33.5 & $<0.001$ \\
\hline Dressing percent, \% & 53.9 & 0.9 & 60.3 & 2.01 & $<0.001$ \\
\hline Conformation class, points & 4.0 & 0.0 & 2.4 & 0.6 & $<0.001$ \\
\hline Fat class, points & 2.6 & 0.7 & 2.1 & 0.3 & 0.011 \\
\hline Cold carcass weight, kg & 351.8 & 23.4 & 445.8 & 33.6 & $<0.001$ \\
\hline Meat $^{\mathrm{a}}, \mathrm{kg}$ & 269.0 & 19.2 & 355.6 & 30.9 & $<0.001$ \\
\hline Meat $^{\mathrm{a}}, \%$ & 76.7 & 1.3 & 80.1 & 1.8 & $<0.001$ \\
\hline Subcutaneous fat ${ }^{\mathrm{e}}, \mathrm{kg}$ & 19.6 & 4.6 & 20.9 & 3.5 & 0.332 \\
\hline Subcutaneous fat ${ }^{\mathrm{e}}, \%$ & 5.6 & 1.2 & 4.7 & 0.8 & 0.020 \\
\hline Bones $^{\mathrm{a}}, \mathrm{kg}$ & 55.5 & 3.4 & 58.9 & 4.5 & 0.013 \\
\hline Bones $^{\text {a }}$, \% & 15.8 & 1.1 & 13.3 & 1.1 & $<0.001$ \\
\hline Tendons ${ }^{\mathrm{a}}$, kg & 7.8 & 0.4 & 9.9 & 2.7 & 0.003 \\
\hline Tendons ${ }^{\mathrm{a}}$, \% & 2.2 & 0.2 & 2.3 & 0.7 & 0.863 \\
\hline
\end{tabular}

Table 5

Fat depots of bulls at 18 months of age (Fettdepots von Bullen im Alter von 18 Monaten)

\begin{tabular}{|c|c|c|c|c|c|}
\hline & \multicolumn{2}{|c|}{$\begin{array}{c}\text { German Holstein } \\
\text { n }=18\end{array}$} & \multicolumn{2}{|c|}{$\begin{array}{l}\text { Charolais } \\
\mathrm{n}=18\end{array}$} & \multirow[b]{2}{*}{$P$-value } \\
\hline & Mean & $\mathrm{SD}$ & Mean & SD & \\
\hline Gut fat, kg & 11.58 & 2.78 & 7.96 & 1.63 & $<0.001$ \\
\hline Gut fat ${ }^{\mathrm{a}}, \quad \%$ & 1.96 & 0.43 & 1.18 & 0.25 & $<0.001$ \\
\hline Omental fat, kg & 20.34 & 4.48 & 13.45 & 2.78 & $<0.001$ \\
\hline Omental fat ${ }^{\mathrm{a}}$, \% & 3.45 & 0.67 & 1.99 & 0.38 & $<0.001$ \\
\hline Kidney fat, kg & 19.13 & 4.68 & 13.99 & 3.18 & $<0.001$ \\
\hline Kidney fat ${ }^{\mathrm{a}}$, \% & 3.23 & 0.71 & 2.07 & 0.46 & $<0.001$ \\
\hline Scrotum fat, kg & 4.21 & 0.66 & 3.30 & 0.65 & $<0.001$ \\
\hline Scrotum fat ${ }^{\mathrm{a}}, \%$ & 0.71 & 0.09 & 0.49 & 0.09 & $<0.001$ \\
\hline
\end{tabular}

${ }^{\mathrm{a}}$ in relation to empty body weight

The Holstein bulls gained more fat in the body cavity, which was consistent to DOLEZAL et al. (1993), who found greater internal fat depots in large framed dairy breeds than in beef breeds. The amount of fat accretion varies with the intake of energy 
(BROSH et al., 1995). Due to the identical feeding regime in this experiment, the different fat accumulation in the investigated animals was probably caused by different fat accumulation mechanisms (KÜHN et al., 2002). This observation is supported by BALDWIN et al. (2004) and SEGERT et al. (1996). They investigated the visceral fat turnover in Holstein cows during lactation, and found fat as an energy source to compensate the metabolic workload of energy in the early lactation in combination with increased liver cell size, which reflects the role of the liver in fat turnover. These findings confirm the ability of Holstein cattle as a dairy breed to accumulate fat as an energy depot and are consistent with the observations of SEGERT et al. (1996), who investigated the mobilization of fat depots in Holstein cows. They also concluded that mobilizing internal fat depots will stabilize the whole energy homeostasis in lactation in Holstein cows.

Comparing the data about nutrient intake, feed conversion, and carcass characteristics (Tab. 1, 2, and 4), the Holstein bulls gained less BW with the same amount of nutrients than the Charolais bulls. This could be explained with the energy content of fat, which has more than twice $(2.23: 1)$ the energy content of protein. Due to the higher energy density of fat, the Holstein bulls have to utilize more nutrients to build up fat depots. SPRINKLE et al. (1998) found, that this works on the expense of ADG, which is indeed lower in the Holstein bulls within this study.

Against the background of an identical feeding regime, the present data also indicate a lower capability for protein accretion in the Holstein bulls compared to the Charolais bulls. Hence, the Holstein bulls could not metabolize the nutrients for protein accretion and rerouted the ingested energy in internal fat depots. OWENS et al. (1995) assumed, that cattle with larger mature body size and capable of faster rates of gain, deposit more protein per unit of fat gain. This can explain the different protein accretion with the same feed intake in this study. At the other hand, the increased protein accretion of the Charolais is probably associated with a greater energy request for "maintenance", because a high protein accretion is associated with a higher protein turnover (BERGEN and MERKEL, 1991).

Table 6 shows the weight of selected tissues and organs and their weight in relation to EBW, which demonstrates additional differences between the investigated breeds. In Holstein bulls, the greater weights of liver and pancreas appear to be of interest. These organs are involved in the nutrient turnover. FORREST (1977) found also different organ weights in Holstein steers in comparison to Holstein x Charolais crossbreds and had no explanation for the heavier liver (4.6\%) of Holstein. BALDWIN et al. (2004) reported greater liver weights against the stage of lactation in Holstein cows and draw conclusions to an augmented nutrient turnover.

The Holstein bulls in this study showed greater $(P<0.001)$ weights of pancreas as well as greater $(P<0.001)$ percentage of pancreas. TERRY et al. (1990) found a comparable percentage $(0.09 \%)$ of pancreas in Holstein steers and BELLMANN et al. (2004a) found 1.5 fold higher insulin plasma levels in Holstein bulls compared to Charolais bulls. These data support the evidence for a greater weight of this organ in Holstein bulls. A correlation between insulin secretion and pancreas size in cattle is not yet proved. Further experimentation should be done on this topic.

The weight of stomachs and the large intestine showed no differences between the investigated Charolais and Holstein bulls. The weight $(P=0.005)$ and the percentage $(P$ $<0.001$ ) of the small intestine in the Holstein bulls differs from the data of the Charolais 
bulls. ISTASSE et al. (1990) found a greater percentage of gastrointestinal tracts in Holstein bulls in comparison to Blue Belgian bulls, referred to BW, which was confirmed by ENDER (1998). The hide was heavier $(P<0.001)$ in the investigated Charolais bulls but showed no differences $(P=0.227)$ in percentage to EBW. ARTHUR et al. (1995) found hide weights of $28.1 \mathrm{~kg}$ in Charolais sired crossbred steers at the age of approximately 16 months, which was around $8 \%$ of their slaughter weight. The amount of blood in the EBW was not different $(P=0.196)$ but percentage of blood showed differences $(P=0.006)$, which could be traced back to the greater EBW of the investigated Charolais bulls (Tab. 6).

Table 6

Organs of bulls at 18 months of age (Organe der Bullen im Alter von 18 Monaten)

\begin{tabular}{|c|c|c|c|c|c|}
\hline & \multicolumn{2}{|c|}{$\begin{array}{l}\text { German Holstein } \\
\qquad \mathrm{n}=18\end{array}$} & \multicolumn{2}{|c|}{$\begin{array}{c}\text { Charolais } \\
\text { n }=18\end{array}$} & \multirow[b]{2}{*}{$P$-value } \\
\hline & Mean & SD & Mean & SD & \\
\hline Blood, kg & 24.76 & 3.08 & 25.99 & 2.51 & 0.196 \\
\hline Blood $^{\mathrm{a}}, \%$ & 4.13 & 0.34 & 3.89 & 0.37 & 0.006 \\
\hline Hide, kg & 45.43 & 3.83 & 54.30 & 6.34 & $<0.001$ \\
\hline Hide $^{a}, \%$ & 7.73 & 0.55 & 8.08 & 0.97 & 0.227 \\
\hline Stomachs ${ }^{\mathrm{b}}$, kg & 18.63 & 1.99 & 17.45 & 2.29 & 0.108 \\
\hline Stomachs ${ }^{\text {ab }}, \%$ & 3.17 & 0.32 & 2.58 & 0.27 & $<0.001$ \\
\hline Liver, kg & 8.26 & 1.64 & 7.53 & 0.66 & 0.091 \\
\hline Liver $^{\mathrm{a}}$, \% & 1.40 & 0.23 & 1.13 & 0.06 & $<0.001$ \\
\hline Pancreas, kg & 0.81 & 0.18 & 0.58 & 0.09 & $<0.001$ \\
\hline Pancreas ${ }^{\text {a }}$ \% & 0.137 & 0.026 & 0.086 & 0.012 & $<0.001$ \\
\hline Small intestine, $\mathrm{kg}$ & 7.22 & 1.02 & 6.32 & 0.72 & 0.005 \\
\hline Small intestine ${ }^{\mathrm{a}}, \%$ & 1.23 & 0.15 & 0.94 & 0.11 & $<0.001$ \\
\hline Large intestine, kg & 4.04 & 1.75 & 3.80 & 0.57 & 0.582 \\
\hline Large intestine ${ }^{\mathrm{a}}$, \% & 0.69 & 0.29 & 0.57 & 0.09 & 0.098 \\
\hline
\end{tabular}

${ }^{\mathrm{a}}$ in relation to empty body weight $;{ }^{\mathrm{b}}$ rumen, psalterium, abomasum

Table 7

Meat quality in LD of bulls at 18 months of age (Fleischqualität im LD der Bullen im Alter von 18 Monaten)

\begin{tabular}{|c|c|c|c|c|c|}
\hline & \multicolumn{2}{|c|}{$\begin{array}{c}\text { German Holstein } \\
\qquad \mathrm{n}=18\end{array}$} & \multicolumn{2}{|c|}{$\begin{array}{c}\text { Charolais } \\
\mathrm{n}=18\end{array}$} & \multirow[b]{2}{*}{$P$-value } \\
\hline & Mean & SD & Mean & SD & \\
\hline LD weight, kg & 6.52 & 0.66 & 9.75 & 0.91 & $<0.001$ \\
\hline Cross section area, $\mathrm{cm}^{2}$ & 82.14 & 10.22 & 125.8 & 12.18 & $<0.001$ \\
\hline Marbling score ${ }^{\mathrm{a}}$, points & 2.78 & 0.55 & 2.06 & 0.64 & 0.001 \\
\hline Intramuscular fat, \% & 4.06 & 1.67 & 2.62 & 1.75 & 0.016 \\
\hline Brightness $^{\mathrm{b}}$, L* $^{*}$ & 33.68 & 2.35 & 38.16 & 2.15 & $<0.001$ \\
\hline Water binding capacity, \% & 27.93 & 3.04 & 30.74 & 3.09 & 0.009 \\
\hline Shear force $24 \mathrm{~h}, \mathrm{~kg}$ & 17.72 & 4.03 & 17.03 & 3.46 & 0.593 \\
\hline Shear force $14 \mathrm{~d}, \mathrm{~kg}$ & 10.97 & 3.17 & 11.17 & 1.84 & 0.826 \\
\hline $\mathrm{pH}_{24}$ & 5.62 & 0.13 & 5.61 & 0.15 & 0.823 \\
\hline
\end{tabular}

${ }^{a}$ marbling score based on a six point scale, where $1=$ extreme low marbling and $6=$ extreme high marbling

${ }^{\mathrm{b}}$ referring to $\mathrm{L}^{*} \mathrm{a}{ }^{*} \mathrm{~b}^{*}$ CIE Lab system 


\section{Meat quality}

For the comparison of the meat quality traits, the LD was analyzed (Tab. 7). The Charolais showed a greater weight $(P<0.001)$ and cross sectional area $(P<0.001)$ of the LD than Holstein bulls, which was in agreement with FORREST (1977) and GERHARDY et al. (1995).

The Holstein bulls showed a higher marbling score $(P<0.001)$ and the intramuscular fat content in the LD was greater $(P=0.016)$. The higher marbling score of the Holstein in comparison to Charolais was previously reported by MARSHALL (1994). MANDELL et al. (1997) observed a comparable intramuscular fat content in Charolais steers.

The colour of the LD cross sectional area was darker in the Holstein bulls $(P<0.001)$. PURCHAS et al. (1997) found similar data in Sahiwal-Friesian cross bulls and GERHARDY et al. (1995) reported brighter L* values in Charolais x Holstein crossbred bulls compared with Holstein bulls. In addition, CHAMBAZ et al. (2001b) found that Charolais have brighter color of LD in comparison to other beef breeds. The Holstein bulls showed more water binding capacity of the LD $(P=0.009)$ compared with the investigated Charolais bulls.

The observed animals in this study showed no differences in tenderness of the LD after $24 \mathrm{~h}(P=0.593)$ and 14 days $(P=0.826)$. GERHARDY et al. (1995) reported similar shear force values in Charolais $x$ Holstein and in purebred Holstein bulls. No differences were recorded $(P=0.823)$ in the $\mathrm{pH}$ of the LD after $24 \mathrm{~h}$ between the investigated bulls. Charolais and Holstein bulls as large framed, late maturing breeds, raised and fattened under identical conditions showed differences in feed conversion, carcass composition, and meat quality at the age of 18 months. Holstein cattle as a dairy breed accumulated more internal fat as an energy depot. Charolais as a beef breed were able to extended protein accretion in the carcass. This indicates different fat accumulation mechanisms between the breeds. The data will be the starting point for further investigations to reveal the underlying pathways of different nutrient utilization in cattle. These insights will be useful for improving feed efficiency and breed adapted feeding.

\section{References}

ASSOCIATION OF OFFICIAL AGRICULTURAL CHEMISTS:

Official methods of analysis. 12th ed. AOAC, Washington, DC. 2000

ARTHUR, P. F.; HEARNSHAW, H.; JOHNSTON, D.; STEPHENSON, P. D.:

Evaluation of Angus, Charolais and Hereford as Terminal Sire breeds on Hereford and First-cross Cows II, Carcase characteristics and retail Yield of Progeny. Aust. J. Agric. Res., 46 (1995), 1245-1258

BALDWIN, R. L.; MCLEOD, K. R.; CAPUCO, A. V.:

Visceral tissue growth and proliferation during the bovine lactation cycle. J. Dairy Sci., 87 (2004), 2977-2986

BELLMANN, O.; WEGNER, J.; TEUSCHER, F.; SCHNEIDER, F.; ENDER, K.:

Muscle characteristics and corresponding hormone concentrations in different types of cattle. Livest. Prod. Sci., 85 (2004a), 45-57

BELLMANN, O.; WEGNER, J.; TEUSCHER, F.; SCHNEIDER, F.; VOIGT, J.; DERNO, M.; SAUERWEIN, H.; WEINGÄRTNER, J.; ENDER, K.:

Beef versus dairy cattle: a comparison of metabolically relevant hormones, enzymes and metabolites. Livest. Prod. Sci., 85 (2004b), 41-54

BELLOWS, R. A.; STAIGMILLER, R. B.; ORME, L. E.; SHORT, R. E.; KNAPP, B. W.:

Effects of Sire and Dam on late-pregnancy conceptus and Hormone traits in beef cattle. J. Anim. Sci., 71 (1993), 714-723

BERG, R. T.; WALTERS, L. E.:

The meat animal: Changes and Challenges. J. Anim. Sci., 57 (1983), 133-146

BERGEN, W. G.; MERKEL, R. A.: 
Protein accretion. In: A. M. Pearson and T. R. Dutson (Ed.) Growth Regulation in Farm Animals, Advances in Meat Research Volume 7. Elsevier Applied Science, London., (1991), 169-202.

BLOCK, H. C.; MCKINNON, J. J.; MUSTAFA, A. F.; CHRISTENSEN, D. A.: Manipulation of cattle growth to target carcass quality. J. Anim. Sci., 79 (2001), 133-140

BÖHME, H:; GÄDEKEN, D.:

Der Brennwert von Körperprotein und Körperfett von Schweinen und Rindern unterschiedlicher Lebendmasse. Z. Tierphysiol. Tierernähr. Futtermittelk. 44 (1980), 165-172

BREIER, B. H.; SAUERWEIN, H.:

Regulation of growth in ruminants by the somatotropic axis. In: Ruminant physiology: digestion, metabolism, growth and reproduction. W. v. Engelhardt, ed. F. Enke Verlag, Stuttgart.1995, pp 451

BROSH, A.; AHARONI, Y.; LEVY, D.; HOLZER, Z.:

Effect of diet energy concentration and of age of Holstein-Friesian bull calves on growth rate, urea space and fat deposition, and ruminal volume. J. Anim. Sci., 73 (1995), 1666-1673

CHAMBAZ, A.; MOREL, I.; SCHEEDER, M.R.L.; KREUZER, M.; DUFEY, P.A.

Characteristics of steers of six beef breeds fattened from eight months of age and slaughtered at a target level of intramuscular fat I. Growth performance and carcass quality. Arch. Tierz., Dummerstorf $\mathbf{4 4}$ (2001a) 4, 395-411

CHAMBAZ, A.; KREUZER, M.; SCHEEDER, M.R.L.; DUFEY, P.A.

Characteristics of steers of six beef breeds fattened from eight months of age and slaughtered at a target level of intramuscular fat II. Meat quality. Arch. Tierz., Dummerstorf 44 (2001b) 4, 473-488

COLEMAN, S. W.; EVANS, B. C.; GUENTHER, J. J.:

Body and carcass composition of Angus and Charolais steers as affected by age and nutrition. J. Anim. Sci., 71 (1993), 86-95

DOLEZAL, H. G.; TATUM, J. D.; WILLIAMS, F. L.:

Effects of Feeder Cattle Frame Size, Muscle Thickness and Age Class on Days Fed, Weight, and Carcass Composition. J. Anim. Sci., 71(1993), 2975-2985

ENDER, B.

Untersuchungen zur Schlachtkörperzusammensetzung und zur Fleischqualität beim wachsenden Rind verschiedener Rassen. Thesis, University of Rostock, Germany 1998

FERRELL, C. L.; JENKINS, T. G.:

Body composition and energy utilization by steers of diverse genotypes fed a high-concentrate diet during the finishing period: II. Angus, Boran, Brahman, Hereford, and Tuli sires. J. Anim. Sci., 76 (1998), 647-657

FORREST, R. J.:

A Comparison of birth growth and Carcass characteristics between Holstein-Frisian Steers and Charolais x Holstein ( $\left.F_{1}\right)$ Crossbreds. Can. J. Anim. Sci., 57 (1977), 713-718

FRELICH, J.; VORISKOVA, J.; KUNIK, J.; KVAPILIK, J.:

Mast- und Schlachtleistungen von Bullen aus Gebrauchskreuzungen tschechischer Rinderrassen mit Fleischrinderrassen. Arch. Tierz., Dummerstorf 41 (1998) 6, 533-544

GERHARDY, H.; KREUZER, M.; LANGHOLZ, H. J.:

Untersuchungen zur Erzeugung von Qualitätsrindfleisch mit schwarzbunten Jungbullen in Mastverfahren mit unterschiedlicher Mastdauer und -intensität. Züchtungskunde, 67 (1995), 117-131

GRAU, R.; HAMM, R.:

Über das Wasserbindungsvermögen im Fleisch. Fleischwirtschaft, 32 (1957), 295

GROSSE, F.; BRETTSCHNEIDER, U.; SAß, G.:

Eine Methode zur direkten Bestimmung des Preßsaftes von Fleisch. Fleisch, 29 (1975), 104

ISTASSE, L.; VAN ENAEME, P.; EVRARD, A.; GABRIEL, P.; BALDWIN, G. MAGHUIN-ROGISTER, G. ; BIENFAIT, J. M.:

Animal performance, plasma hormones and metabolites in Holstein and Belgian blue growing fattening bulls. J. Anim. Sci., 68 (1990), 2666-2673

KOCH, R. M.; CUNDIFF, L. V.; GREGORY, K. E.:

Heritabilities and genetic, environmental and phenotypic correlations of carcass traits in a population of diverse biological types and their implications in selection programs. J. Anim. Sci., 55 (1982), 13191329

KÖGEL, J.; PICKL, M.; ROTT, J.; HOLLOWICH, W.; SARREITER, R.; MEHLER, N.:

Kreuzungsversuch mit Charolais, Blonde d'Aquitaine und Limuosin auf Fleckvieh-Kühe. Züchtungskunde, 72 (2000), 201-216

KÜHN, C.; BELLMANN, O.; VOIGT, J.; WEGNER, J.; GUIARD, V.; ENDER, K.:

An experimental approach for studying the genetic and physiological background of nutrient transformation in cattle with respect to nutrient secretion and accretion type. Arch. Tierz., Dummerstorf 45 (2002), 317-330

MANDELL, I. B.; GULLETT, E. A.; WILTON, J. W.; ALLEN, O. B.; OSBORNE, V. R.: 
Effects of diet, diet breed and slaughter endpoint on growth performance, carcass composition and beef quality traits in Limousin and Charolais steers. Can. J. Anim. Sci., 77 (1997), 23-32

MARSHALL, D. M.:

Breed differences and genetic parameters for body composition traits in beef cattle. J. Anim. Sci., 72 (1994), 2745-2755

MATTHES, H.D.; NÜRNBERG, K.; WEGNER, J.; BITTNER, G., JENTSCH, W.; DERNO, M.:

Schlachtkörperzusammensetzung restriktiv gefütterter Jungbullen unterschiedlich adaptierter Rinderrassen. Arch. Tierz., Dummerstorf 39 (1996) 1, 17-24

OTTO, E.; STANG, N.:

Grundlagenuntersuchungen zur Messung der Zartheit von Rindfleisch. Arch. Tierz., Berlin 18 (1975), 301-310

OWENS, F. N., GILL, D. R.; SECRIST, D. S.; COLEMAN, S. W.:

Review of some Aspects of Growth and Development of Feedlot Cattle. J. Anim. Sci., 73 (1995), 31523172

PURCHAS, R. W.; HARTLEY, D. G.; XUN, Y.; GRANT, D. A.:

An evaluation of the growth performance, carcass characteristics and meat quality of Sahiwal-Friesian cross bulls. N. Z. J. Agric. Res., 40 (1997), 497-506

SACCO, R. E.; BAKER, J. F.; CARTWRIGHT, T. C.; LONG, C. R.; SANDERS, J. O.:

Heterosis retention for birth and weaning characteristics of calves in the third generation of a five-breed diallel. J. Anim. Sci., 69 (1991), 4754-4762

SAS INSTITUTE

Inc., C. N. U. SAS Users Guide statistics: Version 9.3. Cary, N.C. (2003)

SEGERT, A.; LENGERKEN, G. v.; FAHR, R.-D.:

Deposition und Mobilisation von Körperfett bei Milchrindern während der Aufzucht und der 1. Laktation. Arch. Tierz., Dummerstorf 39 (1996) 6, 557-569

SPRINKLE, J. E.; FERRELL, C. L.; HOLLOWAY, J. W.; WARRINGTON, B. C.; GREENE, L. W.; STUTH, J. W.:

Adipose tissue partitioning of limit-fed beef cattle and beef cattle with ad libitum access to feed differing in adaptation to heat. J. Anim. Sci., 76 (1998), 665-673

TERRY, C. A.; KNAPP, R. H.; EDWARDS, J. W.; MIES, W. L.; SAVELL, J. W.; CROSS, H. R.:

Yields of by-products from different cattle types. J. Anim. Sci., 68 (1990), 4200-4205

Received: 2006-08-11

Accepted: 2006-11-23

Authors' addresses

Dr. RALF PFUHL, Research Unit Muscle Biology and Growth

(E-Mail: pfuhl@fbn-dummerstorf.de)

Dr. OLAF BELLMANN, Research Unit Muscle Biology and Growth

(E-Mail: bellmann@fbn-dummerstorf.de)

PD Dr. CHRISTA KÜHN, Research Unit Molecular Biology

(E-Mail: kuehn@fbn-dummerstorf.de)

Dr. FRIEDRICH TEUSCHER, Research Unit Genetics and Biometry

(E-Mail: teuscher@fbn-dummerstorf.de)

Prof. Dr. KLAUS ENDER, Research Unit Muscle Biology and Growth

(E-Mail: ender@fbn-dummerstorf.de)

Dr. JOCHEN WEGNER, Research Unit Muscle Biology and Growth

(E-Mail: wegner@fbn-dummerstorf.de) (corresponding author)

Research Institute for the Biology of Farm Animals,

Wilhelm-Stahl-Allee 2

18196 DUMMERSTORF / GERMANY 